\title{
Comment on: Diagnostic value of miR-186- $5 p$ for carotid artery stenosis and its predictive significance for future cerebral ischemic event
}

\author{
Siamak Sabour ${ }^{1,2}$ (D)
}

Keywords: Asymptomatic CAS, Cerebral ischemic events, Diagnosis, MiR-186-5p

I read the article by Lv et al. published in Diagn Pathol 2020. They aimed to investigate the diagnostic value of miR-186-5p for asymptomatic carotid artery stenosis (CAS), and its predictive value for future cerebral ischemic events (CIEs) [1]. Sixty-seven cases with asymptomatic CAS and 60 healthy individuals were recruited. Receiving-operator characteristic (ROC) curve was drawn based on sensitivity and specificity analyses. Kaplan-Meier method was applied for the evaluation of the predictive value of miR-186-5p for the occurrence of CIE. They reported that area under the curve (AUC) was 0.91 , with the sensitivity of $89.6 \%$ and specificity of $81.7 \%$ at the cutoff value of 1.22 . Kaplan-Meier method results revealed that high miR-186-5p level was associated with the occurrence of CIEs.

While the article offers insight into the decision that MiR-186-5p is a possible diagnostic biomarker for patients with asymptomatic CAS and predicts the incidence of future CIEs, its conclusion is restricted in three ways. First,knowledge of the reported estimates does not provide overall information on the diagnostic and prognostic value of MiR-186-5p in clinical practice. Diagnostic added value is much more important for clinical purposes than the estimates stated [2-5]. Diagnostic

\footnotetext{
Correspondence: s.sabour@sbmu.ac.ir

'Department of Clinical Epidemiology, School of Health and Safety, Shahid Beheshti University of Medical Sciences, Tehran, IR, Iran

${ }^{2}$ Safety Promotions and Injury Prevention Research Centre, Shahid Beheshti University of Medical Sciences, Tehran, IR, Iran
}

knowledge is the information required to address the issue, "What is the possibility of the presence or absence of a particular disease given these test results? " (Research for diagnostic accuracy).

Therefore, diagnostic added value of MiR-186-5p (differences of ROC curves for two diagnostic models with and withour MiR-186-5p) is greatly important in clinical practice. Diagnostic added value of MiR-186-5p may indeed be minimal, although validity estimates may still be excellent. On the other hand, I should mention that as high miR-186-5p level and high degree of carotid stenosis were independent factors for the occurrence of CIEs, one might consider the specificity of these two factors be combined. Combination of the tests are common in clinical practice which increase the specificity and allows to rule in a diagnosis. Second, without determining reliability (precision), we can not judge the diagnostic value of MiR-186-5p. The diagnostic value is determined by the following two parameters: calibration (reliability) and discrimination (accuracy) [2, 6-8].

Third, for medical purposes, the global average approach (Kaplan-Meier method) can not be used to predict of an individual based outcome. In addition, for prediction of CIEs, we require data from two separate cohorts or at least one cohort split into two to first build a prediction model and then test our prediction model. Misleading outcomes are generally the main outcome of the research that fails to test the prediction models [9-

(c) The Author(s). 2020 Open Access This article is licensed under a Creative Commons Attribution 4.0 International License, which permits use, sharing, adaptation, distribution and reproduction in any medium or format, as long as you give appropriate credit to the original author(s) and the source, provide a link to the Creative Commons licence, and indicate if changes were made. The images or other third party material in this article are included in the article's Creative Commons licence, unless indicated otherwise in a credit line to the material. If material is not included in the article's Creative Commons licence and your intended use is not permitted by statutory regulation or exceeds the permitted use, you will need to obtain permission directly from the copyright holder. To view a copy of this licence, visit http://creativecommons.org/licenses/by/4.0/ The Creative Commons Public Domain Dedication waiver (http://creativecommons.org/publicdomain/zero/1.0/) applies to the data made available in this article, unless otherwise stated in a credit line to the data. 
11]. Therefore, reporting association $(\mathrm{HR}=4.1)$ even statistically significant do not gurrantee correct prediction.

I therefore claim that there are certain technical weaknesses and strategies to fix them when determining the predictive and diagnostic value of MiR-186-5p; otherwise, misinterpretation can not be eliminated.

\section{Abbreviations}

miRNAs: MicroRNAs; CAS: Carotid artery stenosis; CIEs: Cerebral ischemic events; ROC: Receiving-operator characteristic; HRs: Hazard ratios;

AUC: Under the curve

\section{Acknowledgements}

Not applicable.

\section{Author's contributions}

SS wrote and revised the manuscript. The author read and approved the final manuscript.

\section{Funding}

None.

Availability of data and materials

Not applicable.

Ethics approval and consent to participate

Not applicable.

\section{Consent for publication}

All study subjects gave written informed consent for publication.

\section{Competing interests}

The author declares that he has no competing interests.

Received: 5 August 2020 Accepted: 18 November 2020

Published online: 22 November 2020

\section{References}

1. Lv W, Zhang T, Zhao H, He S, Li B, Gao Y, et al. Diagnostic value of miR-186$5 p$ for carotid artery stenosis and its predictive significance for future cerebral ischemic event. Diagn Pathol. 2020;15(1):101.

2. Grobbee DE, Hoes AW. Clinical epidemiology: principles, methods, and applications for clinical research. 2nd ed. Burlington: Jones and Bartlett Publisher, United State; 2015.

3. Sabour S, Ghassemi F. Accuracy, validity, and reliability of the infrared optical head tracker (IOHT). Invest Ophthalmol Vis Sci. 2012;53(8):4776.

4. Sabour S, Farzaneh F, Peymani P. Evaluation of the sensitivity and reliability of primary rainbow trout hepatocyte vitellogenin expression as a screening assay for estrogen mimics: methodological issues. Aquat Toxicol. 2015;164: 175-6.

5. Sabour S. Validity and reliability of the 13C-methionine breath test for the detection of moderate hyperhomocysteinemia in Mexican adults; statistical issues in validity and reliability analysis. Clin Chem Lab Med. 2014;52:295-6.

6. Sabour S. A common mistake in assessing the diagnostic value of a test: failure to account for statistical and Methodologic issues. J Nucl Med. 2017; 58:1182-3.

7. Sabour S. Reproducibility of dynamic Scheimpflug-based pneumotonometer and its correlation with a dynamic bidirectional pneumotonometry device: methodological issues. Cornea. 2015;34(5):14-5.

8. Sabour S, Rutten A, van der Schouw YT, et al. Inter-scan reproducibility of coronary calcium measurement using multi detector-row computed tomography (MDCT). Eur J Epidemiol. 2007;22(4):235-43.

9. Sabour S. Obesity predictors in people with chronic spinal cord injury: a common mistake. J Res Med Sci. 2014;19(1):80

10. Sabour S, Ghassemi F. Predictive value of confocal scanning laser for the onset of visual field loss. Ophthalmology. 2013;120(6):e31-2.

11. Sabour S. Prediction of preterm delivery using levels of VEGF and leptin in amniotic fluid from the second trimester: prediction rules. Arch Gynecol Obstet. 2015;291(4):719.

\section{Publisher's Note}

Springer Nature remains neutral with regard to jurisdictional claims in published maps and institutional affiliations.

\section{Ready to submit your research? Choose BMC and benefit from:}

- fast, convenient online submission

- thorough peer review by experienced researchers in your field

- rapid publication on acceptance

- support for research data, including large and complex data types

- gold Open Access which fosters wider collaboration and increased citations

- maximum visibility for your research: over $100 \mathrm{M}$ website views per year

At $\mathrm{BMC}$, research is always in progress.

Learn more biomedcentral.com/submissions 